\title{
Study on Rural Tourism Development Strategy under the Guidance of the Theory of Industrial Cluster
}

\author{
Zhihui Li \\ Pingdingshan Institute of Education \\ Pingdingshan, China
}

\begin{abstract}
As an important support of rural economy development, rural tourism starts to break through the original decentralized management mode and tends to form industrial cluster. To create rural tourism brand and realize sustainable development of rural tourism, industrial cluster is the basic solution. According to the basic theory of industrial cluster and based on the value coherence point between the theory of industrial cluster and rural tourism development, this paper summarized the practical experience of rural tourism and explored the only way of rural tourism upgrading strategy under the guidance of the theory of industrial cluster.
\end{abstract}

Keywords-industrial cluster; rural tourism; industrial upgrading

\section{INDUSTRIAL CLUSTER AND RURAL TOURISM INDUSTRIAL CLUSTER}

As an exotic concept, industrial cluster concept was firstly put forward in America; American scholar Michael E. Porter defined it as a cluster of correlative enterprises and supporting service bodies about same kind of products or the same kind of industries in certain region. The core idea of the theory of industrial cluster is to centralize industries, improve competitiveness and avoid the weakness of individuals. Industrial cluster is the inevitable approach of industrial restructuring and optimization and will help to establish regional brand. Michael E. Porter also put forward that among various industries, tourism is an industry suitable for industrial cluster.

Based on the analysis on industrial cluster concept, rural tourism industrial cluster can be defined in a certain region, in which industry factors related to tourism are connected to each other systematically, forming a large-scale tourism cluster. The core of rural tourism cluster is to break through the independent management situation of the original rural tourism, realize the cooperation between different villages in the same region, between different tourism projects in the same village and between different departments of the same tourism project, thus enhancing the competitiveness of rural tourism.

\section{VAlue AsSESSMENT: NATURAl CoHERENCE BETWEEN THE THEORY OF INDUSTRIAL CLUSTER AND RURAL TOURISM DEVELOPMENT}

Through careful assessment of the theory of industrial cluster and rural tourism, natural coherence between their final values is found. The most important factor influencing rural tourism development is rural tourism brand, and the building of rural tourism brand shall be based on industrial cluster. [1]25Brand represents the image of rural tourism; through simple name or symbol, it can represent the local rural tourism features incisively and vividly and make consumers distinguish the brand in the region from other tourism product more easily. Compared to other products, tourism product is more special: it is centered by regional landscapes and supported by service (the combination of the two), which gives it the feature of intangible product. Therefore, the whole communication process of rural tourism development shall be realized through brand materialization. Since the rural tourism competition in $21 \mathrm{st}$ century becomes more and more intensive, only through establishing a comprehensive tourism brand in a certain region, can you keep a foothold in the intensive competition. As a result, the building of rural tourism brand shall be focus on tourism region. From the aspect of a small individual region, every village inherits its regional cultural features depending on their congenital resource advantages; however, these villages in small individual regions has no advantage of a large-scale tourism region obviously; only by gathering them together and realizing industrial cluster, can the advantage in building tourism brand be exerted and the individual weakness be avoided. Through the cooperation between enterprises and inner-enterprise cooperation, landscape resources, cultural resources and service resources can be combined well, thus, the influence of tourism region can be improved and regional rural tourism brand can be built. From this aspect, the building of rural tourism brand shall be based on industrial cluster.

\section{PRACTICE AND INTROSPECTION: SUMMARY OF PRACTICAL EXPERIENCE OF RURAL TOURISM}

Compared to other countries, the rural tourism in our country started late, which passed through the following three historical evolution stages: (1) Peasant-household tourism stage. Small-scale peasant-household tourism mode with obvious household management features firstly 
appeared in our country in the middle of 1980s in Chengdu suburb. In this stage, the consumption level of peasanthousehold tourism was low with single service variety: mainly providing foods and drinks; it was not at its top. (2) Sightseeing agriculture and leisure agriculture stage. In the late 1980s, with the further development of peasanthousehold tourism, many social capital holders realized that this tourism pattern could meet modern urbanian's demand and had a market potential. Therefore, they started to invest large-scale capital in the development of rural tourism, break through the limitation of imperfect infrastructures and single service variety during peasant-household tourism stage, combine service industry, secondary industry and tertiary industry closely, develop the agricultural tourism integrating sightseeing agriculture and leisure, build middle-end and high-end rural tourism consumption pattern based on regional agriculture. [2]22-27 (3) Rural holiday stage. With the further development of sightseeing agriculture and leisure agriculture, its cost performance manifests gradually compared to city holiday and other consumption patterns; consumers spend more holiday time in villages; thus, a new rural tourism pattern, namely rural holiday appears. Compared to the previous two stages, the feature of rural holiday stage is high consumption level; meanwhile, consumers' requirement on rural environment, service quality and infrastructure is higher.

If analyze from the practical experience of rural tourism, our country only has short-term experience; however, we have made a series of achievements in rural tourism development. Meanwhile, the level of our rural tourism industrial cluster is low with three major problems in the development: firstly, government support for the development of rural tourism industrial cluster is insufficient, so there is shortage of funds in rural tourism development. In villages where economic strength is relatively laggard, the development of rural tourism industrial cluster basically depends on the investment of farmers and village committees, while the investment of relevant government sectors is little; this is an important factor that impedes the development of rural tourism industrial cluster. Secondly, government uniform planning is absent. In the current development of rural tourism industrial cluster, many regions make development separately and blindly and the government has not made sufficient demonstration and planning based on the actual situation of local rural tourism resources. Thirdly, cooperation between rural tourism enterprises is insufficient, namely, enterprises make development separately and have not taken advantage of the intra-enterprise resource superiority to realize large scale cluster effect. Besides, in each rural tourism-related enterprise, the coordination between various departments has not meet the requirement of industrial cluster. [3]57-62

\section{RATIONAL CHOICE: RURAL TOURISM UPGRADING STRATEGY UNDER THE GUIDANCE OF THE THEORY OF INDUSTRIAL CLUSTER}

\section{A. Integrating Superior Resources and Enhancing the Cooperation between Rural Tourism Enterprises}

Under the guidance of the theory of industrial cluster, only by enhancing the cooperation between rural tourismrelated enterprises, can the regional influence of rural tourism be expanded and the industrial competitiveness improved. To realize the cooperation between enterprises, the first problem to be solved is how to integrate the advantages and features of various tourism enterprises. [4]186-190Therefore, we shall break through the previous situation of treating rural tourism as a simple development activity of agricultural resources, lay emphasis on the combined development of other tourism resources and tourist attractions in the region and complement each tourism product's advantages in the same region, so as to promote the cooperation between villages, form a industrial cluster of a certain scale and not only satisfy tourists' basic sightseeing requirement, but also satisfy their high-level spiritual needs.

In addition, we shall standardize the development of rural tourism and realize the professional development of rural tourism enterprises continuously. Tourism includes many industrial factors: scenic spots, catering, accommodation, commerce, transportation, etc., so we can classify tourism clusters in villages by industrial category; based on the industrial factors of tourism, mark out explicit scenic region, catering area, accommodation area, shopping area and entertainment area in villages; standardize the development of tourism enterprises in each region according to industrial standard, so that each tourism project can be professionalized, thus supporting the development of upstream tourism projects and laying a foundation for the development of rural tourism industrial cluster. After the professional development of rural tourism enterprises, we shall also establish perfect tourist destination information system, tourism project ordering system, hotel management system, self-service bank settlement system, so as to improve the service efficiency of rural tourism and create good technical condition for the cooperation between tourism enterprises. [5]70-73Meanwhile, we shall also realize the internet connection between rural scenic spots, restaurants and various department of Tourist Administration, establish rural tourism information release system and realize high-level sharing between various departments in the same tourism project. Only in this way, can the cooperation between rural tourism enterprises be realized smoothly.

\section{B. Increasing Capital Investment and Providing Fund Guarantee for Rural Tourism Upgrading}

Capital investment is critical for the development and upgrading of rural tourism industrial cluster. [6]1219Therefore, on the one hand, the government shall increase capital investment and provide good external condition for the centralization of rural tourism. Local government shall set special fund for rural tourism development, mainly support the infrastructure construction in the centralization of 
rural tourism and provide site for the centralization of large scale tourism enterprises. Meanwhile, it shall also accelerate the establishment of software in the centralization of rural tourism, so as to establish more perfect network information system of rural industry centralization region. Besides, the government shall also provide interest-free loan support for enterprises participated in rural tourism centralization region, which can help these enterprises break through their capital dilemma and improve their enthusiasm in participating in rural tourism centralization region. On the other hand, enterprises shall also realize the advantages of industrial cluster, allocate special fund and create condition to enhance the cooperation between enterprises, such as improve computer information sharing system and accelerate the cooperation between enterprises. Since industrial cluster has high requirement on the professionalization of enterprise, some enterprises may be limited by their shortage of fund and can not participate in the cooperation between other rural tourism enterprises. As a result, rural tourism enterprises can introduce social capital, enhance their capital strength through financing and lay a foundation for the large scale cooperation between enterprises.

\section{The Government shall Enhance the Guidance on Rural Tourism Planning and Promote the Formation of Industrial Cluster}

We shall stick to the following three principles in the planning of rural tourism industrial cluster: firstly: the principle of long term. The government shall treat the development of rural tourism industrial cluster as a long-term work, prepare detailed 10-year development plan for rural tourism industrial cluster, give vitality to rural tourism development through the development of industrial cluster and enhance the regional competitiveness of rural tourism enterprises. Secondly: the planning shall be scientific. We shall introduce high-level professional talents into rural tourism industrial cluster and make them participate in the site selection, development and infrastructure construction, etc. of the local rural tourism industrial cluster to ensure it is scientific. Thirdly, the plan shall be implemented step by step. After preparation, the plan for rural tourism industrial cluster shall be implemented step by step, instead of be anxious for success for making political achievements; the establishment of centralized site for rural tourism enterprises does not mean the realization of industrial cluster; instead, only after every plan has been implemented, the popularity of rural tourism industrial cluster is improved continuously and the output value of enterprise in the region is increased continuously, can more rural tourism enterprises be attracted and make industrial cooperation; thus, the level of industrial cluster can be improved continuously.

In the market economy with gradually intensive competition, the rural tourism development of our country is faced with many challenges and opportunities. In the background of industrial restructuring, the upgrade of rural tourism structure is an irresistible trend; we shall break through the previous decentralized operation mode, realize the conversion from "quantity" to "quality", which shall be emphasized on integrating features and enhancing the cooperation between tourism enterprises; meanwhile, we shall increase investment to provide fund guarantee for the upgrade of rural tourism; enhance government planning and guidance on rural tourism to promote the formation of industrial cluster. In this way, we will establish rural tourism brand and explore a route for rural tourism development suitable for our country.

\section{REFERENCES}

[1] Wang Yuncai, Guo Huancheng, Xu Huilin. Principle and Method of Rural Tourism Planning [M]. Beijing: Science Press, 2006, p.25.

[2] Zhuhua. Study on the Interest Groups of Rural Tourism-Take the Sightseeing Tourism in Chengdu Sanshengnong Hongsha Village as Example [J]. Tourism Journal, No. 5, 2006, p.22 - p.27.

[3] Qianjin. Industrial Cluster and Rural Tourism Development [J]. Journal of Guangzhou University (Social Sciences), No. 4, 2007, p.57 - p.62.

[4] Zhang Meng. Improving Regional Tourism Competitiveness through Industrial Cluster [J]. Science of Finance and Economics, No. 5, 2005 , p.186 - p.190.

[5] Xiongkai. Discussion about Rural Image and Rural Tourism Development [J]. Areal Study and Development, No. 3, 1999, p.70 p.73.

[6] Liu Deqian. Discrimination and Analysis on Rural Tourism, Agricultural Tourism and Folk Tourism [J]. TOURISM TRIBUNE, No.3, 2006, p.12 - p.19. 